\title{
A Criminal Law for Citizens
}

\author{
R A Duff ${ }^{1}$
}

\begin{abstract}
Rather than appealing to penal parsimony as a constraint on the otherwise insatiable demands of the criminal justice system, we should develop a positive account of the proper aims of criminal law which shows parsimony, or moderation, to be integral to those aims. We can do this by developing a republican conception of criminal law as a law that citizens impose on themselves: such a law will be modest in its scope, and will provide a criminal process of trial and punishment that addresses those subjected to it with the respect due to them as citizens.
\end{abstract}

\section{Key words}

- Penal parsimony, moderation, republicanism, citizenship, criminal law

\section{Introduction}

'Reinventing penal parsimony' is an admirable but incomplete aspiration. It is admirable because we must seek ways of constraining the apparently inexhaustible appetite for penal harshness in Britain and the United States, but also because parsimony should be a feature of any normative theory of criminal law. Even a decent system of criminal law will be coercive, burdensome and (since it is human) liable to be oppressive; its ambitions must be modest, its operations constrained by a recognition of the harm it can do and of the costs (material and moral) it incurs. However, this aspiration is incomplete, since to make 'parsimony' our sole aim would set penal theorizing in a narrowly negative frame. We would seek ways to limit penality, to constrain criminal law, to resist temptations to overcriminalize (see Husak 2007); but this could distract us from the equally important task of discerning the positive aims that criminal law should serve. If we think that an abolitionism which seeks to abolish criminal law altogether offers the only plausible route towards a decent polity; or if we see criminal law as expressing a pre-rational urge to punish, which we can constrain but cannot eliminate (Playfair 1971): we need not seek a positive theory of criminal law, and can wield a principle

\footnotetext{
Thanks to participants in the 'Reinventing Penal Parsimony' workshop at which a draft of this paper was discussed, and especially to Lucia Zedner for her very helpful commentary.
} 
of penal parsimony as the best way to limit the harm done by criminal law while it survives. But if criminal law has a legitimate role in a civilised polity, we need a positive account of its proper aims, which the principle of parsimony cannot offer. I will argue that a desirable penal parsimony is best secured by explaining parsimony not as a distinct principle, but as an aspect of those proper aims. Following Loader's (2010) suggestion, we should aspire not to penal parsimony, but to penal moderation: whereas 'parsimony' implies a single-minded concern to reduce (which is why it can have pejorative connotations of meanness), 'moderation' implies a concern to find the appropriate mean between extravagance and meanness.

I turn to that argument in Sections 2-3. First, however, I should say something about the aspects of the problem of penal extravagance that especially concern me here.

\section{Aspects of Overcriminalization}

We punish too many people, too harshly and destructively. Much of this undue harshness flows from what happens to offenders after conviction (leaving aside the harms done by the criminal process itself): too many are subjected to modes of punishment that are, in effect if not by design, inhuman, oppressive, and unduly severe. But it also flows from what happens earlier-from the overcriminalization that infects our criminal law (see Husak 2007), given which too many people who should not be criminally liable come to be convicted of offences.

In its simplest form, overcriminalization is a matter of criminalizing types of conduct that should not concern the criminal law: that is why it was right to decriminalize blasphemy, for instance (Criminal Justice and Immigration Act 2008), and why we should decriminalize the use of many currently prohibited drugs (see Husak 2002). But overcriminalization comes in other, subtler forms than that.

As far as substantive criminal law is concerned, two phenomena are noteworthy. One is the addition of criminal offences to non-criminal legislation. Many of the 1,750 new offences since 1997 are of this kind: a statute specifies certain requirements, and makes it an offence to fail to meet them. The other is the creation of an ever wider range of 'ancillary' offences (Abrams 1989), criminalizing conduct that might contribute to the commission of a primary offence or hinder its prevention or detection. Terrorist legislation illustrates this phenomenon. For example, the Terrorism Act 2000 criminalizes failures to give the police information that might assist the prevention or prosecution of terrorist offences (s. 38A); the possession of 'an article in circumstances which give rise to a reasonable suspicion' of terrorist purposes (s. 57); and the collection or possession of 'information of a kind likely to be useful to a person committing or preparing an act of terrorism' (s. 58). 
These offences sometimes include provisions spanning substance and procedure that also expand the scope of the criminal law: they turn what one might expect to be an element of the offence, which the prosecution must prove, into a matter of defence that the defendant must prove. Thus though s. 57 is headed 'Possession for Terrorist Purposes', the prosecution need prove no such purpose; if it proves that the possession gave 'rise to a reasonable suspicion' of terrorist purposes, the onus shifts onto the defendant to 'prove' that his possession was not for any such purpose. ${ }^{2}$ It might be argued that, unlike offences that impose strict liability, ${ }^{3}$ such burden-shifting provisions do not expand the law's scope; they merely alter the procedure by which guilt is proved. That might be true when the defendant's burden is merely evidentiary, so long as the bar for evidentiary sufficiency is quite low: but it is not true when the burden is persuasive, ${ }^{4}$ since an innocent defendant might be unable to produce evidence to prove her innocence; and the over-enthusiastic shifting even of evidentiary burdens still involves penal excess, since it requires citizens to answer in a criminal court for wholly innocent conduct, on pain of conviction and punishment if they cannot offer an exculpatory answer. ${ }^{5}$

We should therefore be alert to ways in which the criminal law's grasp can be extended, often without adequate justification, not only by criminalizing types of conduct remote from the primary mischief at which the law is aimed, but also by weakening the fault requirements in offences, or by shifting probative burdens from prosecution to defence. Penal extravagance is a feature not just of our sentencing laws and practices, or of our penal institutions, but also of the substantive criminal law. The (re)invention of penal parsimony should involve not just reform of sentencing and punishment, but a re-examination of the scope and structure of the substantive criminal law, so that its ambitions remain within suitably modest bounds.

However, not all expansion of the criminal law constitutes overcriminalization; not all reductions in its scope mark a welcome penal parsimony. Not only might there be currently non-criminal wrongs that we should criminalize; one way to 'decriminalize' conduct is to subject it to non-criminal regulation that is as burdensome as the criminal law, but lacks the protection that criminal law gives defendants. One example is the use of 'preventive orders' to control supposedly dangerous individuals without convicting them (see Ashworth and Zedner 2008, 2010): given that alternative, we should prefer criminalization, which requires public proof of determinate wrongdoing before liberty is curtailed, and subjects any such

\footnotetext{
S. 57(2). This does not actually place a persuasive burden on the defendant (see s.118): he need only adduce evidence sufficient to create a reasonable doubt. See generally Ashworth and Blake 1996; Tadros 2007.

For an egregious recent example, see Policing and Crime Act 2009, s. 14.

E.g. Misuse of Drugs Act 1971, ss. 5, 28.

Which is not to say that such burden-shifting can never be justified: see Duff 2007, ch. 10.
} 
curtailment to requirements of proportionality. Another example is the use of non-punitive 'measures'. The Netherlands, for instance, was long seen as a beacon of penal parsimonywith rates of imprisonment and sentence lengths well below those in the UK and the USA (but see Downes and Van Swaaningen 2007); but beside the range of formal punishments there exists a range of compulsory 'measures', including 'placement in an institution for persistent offenders', which (not being punishments) are not constrained by any requirement of retrospective proportionality. ${ }^{6}$ But just as we might prefer criminalization to other modes of regulation, so we might prefer criminal punishment to other kinds of 'measure'; we might do better to try to reform criminal law and punishment, rather than replacing them by other techniques of control or prevention. ${ }^{7}$

None of this is to suggest that penal parsimony is not a worthy aspiration. It does suggest, however, that we need a clearer account of what criminal law and punishment can properly do and be if we are to understand whether, when and why they should be preferred to these or other alternatives: we need not merely a negative, constraining principle of penal parsimony, but an account of the positive justifying aims of a system of criminal law.

\section{How Best to Pursue Penal Parsimony}

There are two grounds on which we might find our current systems of criminal justice to be punitively extravagant. First, we might think that even if they are pursuing legitimate aims, the means used are often, even if effective, inconsistent with other values. Of course it is a proper task for the state to reduce the harms that crime causes, or to protect security, ${ }^{8}$ and criminal law can serve those goals. Our use of it should, however, be constrained not only by the demand that it be used efficiently, but by other values, such as proportionality; current penal practices pay insufficient attention to those other values. Or we might, second, find a more fundamental fault in our current criminal law - that it is not now pursuing the aims that criminal law ought to pursue: what is amiss is not just the means used in pursuit of legitimate ends, but the ends themselves.

These two kinds of criticism reflect two familiar models of penal theorising; the second, I will argue, offers a more appropriate grounding for penal parsimony.

The first kind of criticism fits with a familiar model of normative theory (see Hart 1968). We begin with a 'general justifying aim' for a system of criminal law, which gives us

'Instelling Stelselmatige Daders': on this and other 'measures' see de Keijser (forthcoming).

Compare too the 'decriminalization' involved in the introduction of Ordnungswidrigkeiten in German law: Gesetz über Ordnungswidrigkeiten (1968/1975); Weigend 1988; Öztürk v Germany (1984) 6 EHRR 409.

8 Depending on what 'security' should mean: see Zedner 2009, ch. 1. 
positive reason to create such a system. We realise, however, that the unconstrained pursuit of that aim would violate other important values: not only would it conflict with other goals; it would violate normative demands that are naturally expressed in terms not of goods to be achieved, but of wrongs not to be committed. Perhaps the justifying aim of criminal law is to reduce those kinds of harm whose incidence can be affected by proscribing (or prescribing) certain kinds of human conduct; a system of criminal law is justified only if it is an efficient means to that end. But demands of justice also set categorical side-constraints on the means we may use in pursuit of our goal - the right of the innocent not to be punished, for instance, or the right of the guilty not to be punished more harshly than they deserve; ${ }^{9}$ we must not pursue the justifying aim by means that violate such side-constraints. On this view what is wrong with current penal practice might be not that it is pursuing the wrong ends, but that in pursuit of legitimate goals it violates side-constraints of justice that it should respect.

This kind of model usually involves a consequentialist end, consisting in some benefit to which criminal law is an efficient means, and a set of non-consequentialist side-constraints. It is a tempting model, which seems to do justice to two kinds of moral demand that most of us recognise: the demand to pursue consequential goods, and the demand that we refrain from actions that are intrinsically wrong. If ours is a normatively plural world, of consequentialist and non-consequentialist values, this type of theory allows us to fit both kinds of value into a coherent whole. Some versions of retributivism, however, also fit this model. Moore argues, for instance (1997, 33-5), that the function of criminal law is 'to attain retributive justice', by punishing culpable moral wrongdoers. Now we cannot plausibly talk of a categorical duty to punish all culpable wrongdoers; the most we can say is that this is one significant good that the state should try to achieve through a system of criminal law. That good is internal to the system, rather than a further consequence; but it plays the same role as do consequentialists' further goods, and can ground an account of criminal law of the same form as that displayed in side-constrained consequentialism: we should pursue the goal of punishing all and only the culpably guilty, but must respect side-constraints which limit the scope of the criminal law by appealing to other values (Moore 1997, ch. 16; 2009, 31-3).

Whatever goal is posited, however, whether it is intrinsic or extrinsic to the criminal law, such theories are inherently unstable (see Goldman 1979; Lacey 1988, 46-56). It is hard to believe that the side-constraints of justice are absolute: that we must refrain from injustice, although the heavens fall. If the heavens would fall, if we face an emergency, the demands of

Such side-constraints are more familiar in the context of punishment than in that of criminalization, but we can readily develop such a model for criminalization: see Husak 2007; Moore 1997, ch. 16. 
justice might be overridden by the demand that we avert disaster. But once we recognise that emergencies can force us to violate the demands of justice, we might be tempted to discern emergencies too enthusiastically: in a 'war' against terrorism, or drugs, or crime, we might have to compromise some of what will then seem to be the niceties of justice-niceties that must be respected in times of stable peace, but cannot be fully protected in an emergency.

Penal parsimony can be portrayed as a side-constraint: in pursuit of the ends that criminal law should serve, we must be frugal in our use of its coercive means. Admittedly parsimony was for Bentham, as for any consequentialist, also integral to the end: the aim of criminal law is the efficient, i.e. parsimonious, pursuit of the relevant goods. That kind of parsimony is, however, insufficient, since consequentialist ends might be efficiently pursued by excessively harsh or coercive means. So we might posit a principle of parsimony as a further check on consequentialist penality: we should restrain the scope and rigours of the criminal law, even at the cost of some loss of efficiency in our pursuit of its aims. Parsimony, like other sideconstraints, then draws its force not from within the criminal law's aims, but from outside it: it is therefore vulnerable to the same kind of over-riding in times of (perceived) emergency.

Of course, the fact that a theory makes normative life uncomfortable is not an objection to the theory. Perhaps that is how the normative world is - a site of fundamental normative conflicts, where we face dilemmas that we cannot coherently resolve; ${ }^{10}$ a normative theory of any human institution must reflect that messiness, and force us to face those conflicts. If we fear that we may be tempted to discern emergencies too quickly, the proper remedy is not to look for another theory, but to find ways to strengthen our moral will and perspicacity. But if there was a more stable kind of theory, which did not make penal policy vulnerable to hijack by perceived emergencies, that would be something in its favour.

We can reach the same point by a different route. Braithwaite and Pettit talk of the need to posit a 'satiable' goal for criminal law, which motivates 'respect for uncontroversial limits' on the law's powers, and does 'not make voracious demands' that threaten those limits (1990, 45). Familiar consequentialist goals, such as crime prevention, are 'inherently insatiable: for however much we do, 'there will always be more that can in principle be achieved'; but we could achieve that more only by transgressing such 'uncontroversial limits' as refraining from punishing known innocents $(1990,46) .{ }^{11}$ We can constrain that insatiability by setting sideconstraints on our pursuit of the goal; but this produces an unstable theory whose constraints

10 A constant theme of one kind of liberal thought: see e.g. Nagel 1978.

11 Of course, if what we are looking for (as they are) is a goal for the whole system of criminal justice, crime prevention is not a candidate: a comprehensive theory of criminal justice must include an account of the proper scope of the criminal law, i.e. of what should count as a crime. 
are liable to be overwhelmed by the perceived urgency of the end. If, however, we can posit a satiable end, we can generate a more stable theory.

It might seem that while consequentialist theories are inherently insatiable (because they take the end to justify any efficient means), retributivist theories are not: it could not further retributive justice to punish a known innocent. But if we interpret retributivism as positing a good to be achieved, it too can be insatiable. Consider again Moore's retributivism, according to which criminal law aims to punish culpable moral wrongdoers. There is no lack of such wrongdoers in the world; however many we punish, there are more out there; there is no end to the pursuit of that end. That is why Moore $(1997$, ch. 16) appeals to other values, extrinsic to the proper aims of criminal law, to produce a tolerable account of its legitimate scope.

Braithwaite and Pettit claim to posit a satiable consequentialist goal for criminal law: that of 'dominion'. It is not clear that they are right: just as a large enough gain in the goods that other consequentialist theories posit could mandate policies which violate 'uncontroversial limits', so a large enough gain in the dominion of the many could justify invasions of the dominion of the few that violate such limits. Instead of pursuing this issue, however, I will sketch an alternative satiable goal for criminal law. The key point, as Braithwaite and Pettit see, is to posit a goal that is moderate in ambition: one that does not even tempt us towards excess in its pursuit. We can then make parsimony, understood now as moderation, internal to the criminal law, rather than having to control the criminal law by constraints based in external values. Two examples might make this point clearer.

First, contrast Moore's account of criminal law with another that takes wrongdoing to be its proper focus. For Moore, all wrongdoing is in principle the criminal law's business. If we are to understand why such wrongs as marital infidelity, or betraying a friend's confidence, should not be criminal, we must look not to the criminal law's proper end (these are culpable wrongdoings that the criminal law should aim to punish), but to other principles, external to that end, which constrain its pursuit: for instance, to the 'presumption of liberty' (see Moore 1997, 746-50). If, by contrast, we say that the criminal law is concerned only with 'public' wrongs, wrongs that are the business of all members of the polity (Marshall and Duff 1998), we can explain why in terms of the criminal law's own aims, marital infidelity or betraying a friend's confidence should not be criminal. The reason is not that, whilst we have reason to criminalise such wrongs, we have stronger reasons (extrinsic to the criminal law's goals) not to do so; it is that we have no reason to criminalize them, since they are not public wrongs. Rather than picturing a system of law whose intrinsic aims would mandate the pursuit of all moral wrongs, we picture a system whose intrinsic aims are modest from the start. 
Second, consider the idea of 'abuse of process' in relation to the criminal trial. If we ask why courts should, for instance, exclude evidence that was obtained by torture; or bar the trial of someone who is present for trial only because he was repatriated illegally by state officials or with their connivance: ${ }^{12}$ one answer is that whilst it could still serve the ends of justice to admit such evidence or to try such a defendant, other extrinsic values which bear on the trial make it improper to admit the evidence or to continue the trial (for instance, the need to deter malpractice by state officials by making it unprofitable). But that would not capture the idea, which courts cite in such contexts, that it would be an 'abuse of process' to pursue a trial on the basis of such evidence, or when the defendant was brought to trial in this way; or that it would undermine the 'integrity' or 'legitimacy' of the trial. ${ }^{13}$ To call something an abuse of process is to say that a process is being put to an improper use, at odds with its proper aims; to say that something undermines the integrity or legitimacy of a process is to say that it is inconsistent with the proper ends, or intrinsic values, of that process. We must then ask more carefully just what the proper aims of the criminal trial are. If the aim is simply to establish whether the defendant is guilty and eligible for punishment, it can be served by admitting evidence acquired by torture, or trying an illegally repatriated defendant. But suppose that it is, rather, to do justice by calling alleged wrongdoers to account under the law: that process is vitiated by state action that blatantly violates the demands of justice and the law. A state that kidnaps (or connives in the kidnapping of) a defendant cannot claim to call him to account under the law that it violates. A state that uses (or connives in) torture to extract evidence cannot claim to be doing justice, or to be treating those involved in the criminal process with the respect that is due to them (see Duff et al. 2007, chs. 3, 8).

I have argued so far that if we treat a principle of parsimony merely as a constraint on the criminal law, restraining our use of coercive means in pursuit of the law's legitimate goals, it will be vulnerable to demands flowing from the perceived urgency of those goals, especially in times of perceived emergency_-just when it is most important. I have also suggested that we can find a securer basis for parsimony by portraying it not as a side-constraint, flowing from values external to the proper ends of the criminal law, but as integral to those ends: we can then avoid the conflicts between ends and constraints that bedevil the 'side-constraint' model—conflicts that the ends are always likely to win. We can now explore that possibility.

12 See $A$ and Others $v$ Secretary of State for the Home Department [2005] UKHL 71; $R v$ Horseferry Road Magistrates' Court, ex p Bennett (1994) 98 Cr App Rep 114 (contrast US v Alvarez-Machain 504 US 655 (1992)).

13 See Ashworth 2002; Dennis 2007, ch. 2E. 


\section{A Criminal Law for Citizens?}

Normative theorising about criminal law typically starts with the aims of criminal law: what are its proper purposes? But there is a prior question: who is criminal law for? It might be addressed partly to courts (Dan-Cohen 1984; Alldridge 1990), but it is not addressed only to them: it speaks as well to those with whom the courts will deal. ${ }^{14}$ Before we ask what its aims are, we must therefore ask how it should portray those whom it claims to bind, and how it should speak to them.

A simple answer is that law claims to bind, and is addressed to, citizens. If we focus on domestic law, that answer seems unavoidable; it might indeed be a definitional truth-and thus unhelpful, since it shifts the question to that of what it is to be a citizen. That question must be answered through political theory: if we are to understand the criminal law, as a core institutions of the state, we must begin with an account of the state' proper responsibilities and aims, and of its proper relationship to its citizens.

This is not the place to offer a full political theory. But to work towards a conception of a suitably modest criminal law, we can ask what citizenship can mean in contemporary polities that aspire to become liberal democracies. ${ }^{15}$ The best answer to that question is to be found in a republican theory that portrays citizenship, understood as equal and mutually respectful participation in the civic enterprise, as a central value (see e.g. Dagger 1997, Pettit 1999).

To give a little more substance to this slogan, we can contrast republican citizenship with two other kinds of status that theorists have ascribed to criminal law's addressees. The first is that of subject. This is explicit in classical legal positivism: law consists in commands that the sovereign addresses to his subjects, who must obey the commands or face sanctions. It is also implicit in accounts that portray criminal law as a set of prohibitions, or as a technique for controlling behaviour: prohibitions, like commands, imply a distinction between those who prohibit and those who must obey; behaviour-controlling techniques are applied by would-be controllers to the population whom they would control. That might capture the sad reality of criminal law in many contemporary societies: the law is heard by many as a set of external demands which will coerce them if they do not obey. What that describes, however, is not the neutral reality of law, but a pathology — one way in which law goes wrong. For a republican, law must be our law as citizens, a 'common' law that we make for ourselves, not a law made for us and imposed on us by a sovereign; citizens must be able to understand themselves as authors as well as addressees of the law (see Cotterrell 1995, ch. 11; Duff 2001, ch. 2.4).

14 Pace Kelsen 1945, 63; see Hart 1994, 35-42.

15 Recognising the different meanings that different theorists have given both to 'democracy' and to 'liberal'. 
The second contrast is with the status of moral agent. Philosophers who look to moral rather than political philosophy sometimes portray citizens, in their dealings with the criminal law, simply as moral agents. That is implied, for instance, by Moore's account. If the criminal law aims to punish morally culpable wrongdoers, it deals with us as moral agents; the fact that the wrong I commit in Scotland is dealt with by a Scottish court under Scots law, while the wrong that a Frenchman commits in France is dealt with by a French court under French law, is of secondary significance, reflecting an appropriate division of moral labour between different states. But this does not take citizenship seriously enough. Citizenship ties us, not to every other moral agent as such, but to the fellow members of a particular polity: ${ }^{16}$ it gives us a particular interest, not in every dimension of our fellows' lives, but in those aspects that bear directly on the civic enterprise in which we are collectively engaged. Citizenship is a communitarian idea, of membership of a community engaged in a particular form of life: but communitarianism need not posit the kind of oppressively all-embracing community that its critics fear. For the civic enterprise is just one of many communities, one of many forms of life, that structure our lives: its scope and reach is limited, partly because a central feature of that form of life in a liberal republic is its emphasis on individual freedom and the privacy that it requires. ${ }^{17}$

Another aspect of republican citizenship is that it is inclusive and not easily lost. The law binds and protects all citizens equally; it speaks to them all in the same terms, whether they are law-abiding, or victims or perpetrators of crime. It does not protect 'us', the law-abiding, against 'them', the enemy; it is not a weapon in a 'war' against drugs, or terrorism, or crime. It is, rather, an expression of the values by which we define ourselves as a polity-values that we should all share. ${ }^{18}$ One who commits a crime does not thereby lose his civic status; he remains a citizen - albeit one whose wrongdoing his fellows must address. That is what is objectionable about the 'civic death' suffered by many convicted of felonies in the US, and about the UK government's continuing failure to remedy the blanket removal of voting rights from prisoners: ${ }^{19}$ they deny citizenship when it should be reasserted.

16 Although there are interesting questions about how the idea of citizenship could develop: can we sensibly talk, for instance, of being citizens of Europe? Can we aspire to talk of being citizens of the world-of humanity as a community, in whose name such bodies as the ICC can claim to act?

Privacy here is a matter of whose business something is: to claim that an aspect of my life is a private matter is to claim not necessarily that others must not know about it, but that it is not their business-they have no standing to inquire, to interfere, to hold me to account for it.

18 One danger is of course that the 'we' who define and articulate these values will constitute only a sub-group of the (supposed) 'we' whom they bind-that too many citizens will find the values defined for them, rather than being able to recognise them as their own. That is one way in which republican aspirations can fail.

19 Despite the ECtHR ruling in Hirst v UK (2006) 42 EHRR 41. 
(Citizenship is not, of course, an unproblematic foundation for criminal law. First, there are important issues about how citizenship is gained, and about whether it can be forfeited. Second, how can a citizens' criminal law address or deal with non-citizens who visit, or who are resident for shorter or longer periods in, the polity? There is clearly a real danger that a citizens' law will be in various ways exclusionary rather than inclusionary: that citizenship will be made unreasonably hard to acquire, or will be too easily lost; that non-citizens will be denied the protection and respect that citizens can expect; that the polity will operate with a distinction between 'citizen' criminal law and 'enemy' criminal law_and will be too quick to classify some kinds of offender as 'enemies' rather than as 'citizens' ${ }^{20}$ I cannot discuss these problems here, save to note that liberal republicans will be sensitive to the import not only of citizenship, but of other normatively rich concepts such as fellow human being, and guest. They will therefore, first, need to ensure that citizenship is rather easy to gain and very difficult to lose; and second, accord to temporary visitors or residents the respect and concern that is due to guests who are both bound and protected by the values that define the polity.)

A first step towards a modest criminal law is to ask what kind of law republican citizens might create. To what kind of criminal law, and what kinds of punishment, might they subject themselves, consistently with a recognition of each other as citizens? However, before we can answer that question, we must ask what criminal law is, as a distinctive mode of regulation. Republicans, I suggest, should see criminal law as properly concerned with public wrongswrongs that are the proper business of all citizens in virtue of their membership of the polity, because they violate the polity's civic life, and the values that structure it. In its substantive dimension, criminal law defines a range of such wrongs; its procedural and penal dimensions provide for formal responses to the suspected commission of such wrongs, with the criminal trial and criminal punishment as the most dramatically visible of such responses.

The trial can now be seen as a process through which a citizen is called to answer, by her fellow citizens, to a charge of public wrongdoing, and to answer for that wrong if it is proved: part of the importance of such a process is that it treats defendants as citizens who are bound by the polity's values and publicly accountable for their conduct. ${ }^{21}$ As for the punishments to which those who are convicted are liable, we must ask not what kinds of punishment 'we' should impose on 'them', but what kinds of punishment we should impose on ourselves and our fellow citizens - and to what ends. I have argued (Duff 2001) that a plausible answer to

20 For a useful English-language introduction to the debate about Bürgerstrafrecht and Feindstrafrecht debate, see Díez 2008.

21 See further Duff 2007, chs. 2, 6, 8; Duff et al 2007. Such an account of the criminal trial is clearly a matter of ideal theory, not of empirical description. 
that question should emphasise not incapacitation or deterrence, but communication: an attempt to bring offenders to recognise the wrongs they have committed, and the need to make appropriate reparation for them. Punishments which serve that end will be modest in their severity, and civil in their modes. They must address offenders as citizens who are still members of the polity: the wrongs they have committed must be addressed (we do not respect our fellows by ignoring their wrongdoing), but in ways that preserve rather than deny the offender's civic standing. Among the implications of this approach are that it will make little use of imprisonment, given both its material harshness and its exclusionary meaning; and that it will seek modes of punishment that can be seen (by offenders and others) as reparatory-as formally repairing offenders' civic relationship with their fellow citizens.

Penal moderation - as to severity and mode of punishment, and as to the tones in which punishment addresses those who are punished-is thus integral to a republican criminal law. That moderation is not imposed as an extrinsic constraint on our pursuit of the proper aims of criminal law. Rather, it is an intrinsic dimension of a republican conception of crime and of those who commit crimes: the aims of republican criminal law cannot be served by harshly oppressive or exclusionary punishments.

A further kind of moderation is intrinsic to a republican criminal law: moderation in the law's scope. To show that we have any reason to criminalize a type of conduct, we must first show that it constitutes a public wrong that concerns all members of the polity as impinging on the values that define the civic enterprise. We must also argue that it requires a criminal response- a response that makes its wrongfulness salient, and that involves calling anyone accused of committing such a wrong to answer to that charge on pain of condemnation and punishment if proved guilty; for that is what criminalizing a type of conduct involves. Two further aspects of criminalization are also important. First, it declares the wrong to be 'public' not just in the sense that it concerns us all, but in the sense that it is one with which we should deal collectively: we do not leave it to the victim to pursue (or not to pursue) the wrongdoer; the wrong, we insist, is ours as well as his. Second, the law's declaration of wrongfulness is categorical, not negotiable. When the defendant is summoned to answer a charge, he can of course offer an exculpatory explanation for his commission of the offence; but it is not open to him to argue that what the law defines as an offence is not a public wrong. ${ }^{22}$ Wrongs which are to be criminalized must be wrongs which we can say must be publicly condemned, and

22 But it is crucial to the law's legitimacy that there is another political forum where he can make that argument and seek to change the law. These features of criminal law are central to abolitionist objections that criminal law 'imposes' values and 'steals' 'conflicts': see Christie 1977; in response see Marshall and Duff 1998, 
whose perpetrators must be called to public account; a liberal republic will be sparing in its declarations of such wrongs.

To say this is not yet to provide any substantive principles of criminalization; but surely we need such principles if we are to limit the scope of the criminal law. I fear, however, that the search for a set of master principles is doomed to failure, since candidate principles (when not so vague as to be vacuous) are either radically under-inclusive or vastly over-inclusive: they cannot do the work they are asked to do. ${ }^{23}$ Criminalization requires a more piecemeal process of public deliberation: what will limit the law's scope is not some master principle(s), but the spirit in which such deliberation is conducted-as deliberation about what we can properly demand of each other as citizens on pain of formal condemnation and punishment. ${ }^{24}$

The spirit of that public deliberation must be informed by civic virtues such as pluralism, civic trust, and respect for responsible agency. That is, first, liberal republicans will realise that what strikes them as objectionably offensive or wrong might reflect a different, respectworthy conception of the good. They need not be neutral between all conceptions of the good - they can be perfectionists; but perfectionists can be pluralists. ${ }^{25}$ They will therefore be slow to criminalize conduct purely on the grounds that it is offensive to others, especially when it is wrong (if at all) only because it is offensive, rather than offensive because it is wrong. ${ }^{26}$

They will, second, take seriously the (defeasible but not easily defeated) presumption that others are to be trusted not to attack them. ${ }^{27}$ That is why their criminal law will normally be responsive rather than pre-emptive: they will be slow to create offences whose mischief lies not in what they actually do, but in what the conduct might lead to in the future-especially when such future mischief will depend on the conduct of others, and is not intended by the agent (see von Hirsch 1996). They will not criminalize the mere possession of material that gives rise even to a reasonable suspicion that it is possessed for terrorist purposes: for that is not yet a wrong for which the possessor should have to answer in a criminal court, on pain of conviction if he cannot adduce evidence that the possession was innocent. ${ }^{28}$ They will see reason to criminalize possession that is for terrorist purposes: for terrorist attacks are public

23 This is, notoriously, true of the harm principle (see e.g. Harcourt 1999; Stewart 2010; Duff 2007, ch. 6).

24 For a sensible discussion of principles and policies that should figure in such deliberation, see Ashworth 2009, chs. 2-3.

25 See Raz 1986. Brown ([1993] 2 All ER 75) neatly illustrates this point: the key to understanding why their sadomasochistic activities should not be criminal lies not in an appeal to the supposedly wrong-dissolving power of consent, but in recognising alternative ways of finding mutually respectful fulfilment.

26 See generally von Hirsch and Simester 2006. The paradigm of conduct that is offensive because it is wrong is the racist insult.

27 Compare Floud and Young 1981, 44, on the 'right to be presumed ... free of harmful intentions'.

28 Terrorism Act 2000, s. 57; see text at n. 2 above. See more generally Dubber 2001. 
wrongs, and preparations to commit public wrongs are themselves public wrongs. However, they will use even 'possession with intent' offences, and other precursor offences, sparingly, since they will see the importance of leaving each other room, as responsible agents, to turn back voluntarily from a criminal path. They will use the criminal law to respond to genuine wrongs that have been committed, rather than to prevent wrongs that are so far only potential or contemplated. ${ }^{29}$

However, third, republicans will not always be reductivist. They will sometimes see good reason to extend the criminal law to cover conduct that was not previously regulated at all, and will sometimes prefer criminal law to other possible modes of legal control. They will, for instance, see reason to use criminal law to deal with breaches of statutory requirements (if they are genuine wrongs, as breaches of regulations that serve the common good) rather than 'decriminalizing' such breaches by redefining them as 'administrative' violations. ${ }^{30}$ They will avoid modes of preventive restraint that cannot be justified as deserved punishments for past wrongdoing, ${ }^{31}$ and will instead use criminal law to define relevant kinds of wrongdoing. The reason for this is again grounded in citizenship and responsible agency: the law should guide citizens' conduct only by offering them relevant reasons for action, grounded in the polity's good; it should subject them to its coercive attentions only when they fail to act in accordance with such reasons, and commit a public wrong; the proper response to such wrongs is to call those who commit them to account, as the criminal law does.

Restraint and moderation will still be features of a republican approach to criminal law, even when it sees reason to extend the criminal law: partly because the criminal process to which alleged offenders are subjected and the punishments to which offenders are liable must still treat them as citizens; and partly because, to the extent that the criminal law is likely to bear too oppressively on alleged and proved offenders, republicans will see good reasons on balance not to criminalize conduct that they had in principle good reason to criminalize.

\section{Conclusion}

The penal moderation to which we should aspire is, I have argued, best grounded not in determinate principles by which we might hope to constrain the state's pursuit of whatever its legitimate goals may be, but rather in a republican conception of criminal law to which a conception of citizenship is central. We should aspire to a criminal law that is apt for citizens:

29 See also Zedner 2007. These aspects of a republican approach to criminal law give clearer content to the idea of criminal law as a 'last resort': see Husak 2004; Jareborg 2005.

30 See n. 9 above; Duff et al 2007, 189-98.

31 See at n. 8 above. 
one to which they can properly and without losing respect for themselves or for their fellow citizens subject themselves and each other.

Two final and less optimistic remarks are in order. First, since the achievement of such a criminal law depends on the inculcation and maintenance of the republican civic virtues that we noted above, it is (to put it mildly) a distant ideal; pending the day when criminal law can bring the goods that it ideally should bring, we also need to pursue a more negative principle of parsimony that seeks to limit the harm the criminal law can do. Second, there remain some serious questions about the conditions necessary for republican criminal law to survive: about the extent to which in which criminal law can deal with, or can be sustained, in various kinds of emergency; about the kinds of emergency that might make its (at least partial) suspension unavoidable. But these are not questions that we can pursue here.

\section{References}

Abrams, N. (1989) 'The New Ancillary Offenses', Criminal Law Forum 2: 1

Alldridge, P. (1990) 'Rules for Courts and Rules for Citizens', Oxford Journal of Legal Studies 10: 487

Ashworth, A. J. (2002) 'Testing Fidelity to Legal Values: Official Involvement and Criminal Justice', in S. Shute and A.P. Simester (eds), Criminal Law Theory: Doctrines of the

General Part (Oxford: Oxford University Press) 299 (2009) Principles of Criminal Law (6th ed). Oxford: Oxford University Press , and Blake, M. (1996) 'The Presumption of Innocence in English Criminal Law',

Criminal Law Review: 306

, and Zedner, L. (2008) 'Defending the Criminal Law: Reflections on the Changing

Character of Crime, Procedure, and Sanctions' Criminal Law and Philosophy, 2: 21 (2010) 'Preventive Orders: A Problem of Under-Criminalization?' in R. A. Duff, L Farmer, S E Marshall, V Tadros and M Renzo (eds), The Boundaries of the Criminal Law

(Oxford: Oxford University Press, 2010)

Braithwaite, J. and Pettit, P. (1990) Not Just Deserts: A Republican Theory of Criminal Justice. Oxford: Oxford University Press

Christie, N. (1977) 'Conflicts as Property’ British Journal of Criminology, 17: 1

Cotterrell, R. (1995) Law's Community. Oxford: Oxford University Press

Dagger, R. (1997) Civic Virtues. Oxford: Oxford University Press 
Dan-Cohen, M. (1984) 'Decision Rules and Conduct Rules: On Acoustic Separation in Criminal Law' Harvard Law Review, 97: 62

de Keijser, J. W. (forthcoming) 'Never Mind the Pain; It's a Measure: Justifying Measures as Part of the Dutch Bifurcated System Of Sanctions', in M. Tonry (ed), Punishment Futures (Oxford: Oxford University Press)

Dennis, I. H. (2007) The Law of Evidence (3rd ed.). London: Sweet and Maxwell

Díez, C. G-J. (2008) ‘Enemy Combatants Versus Enemy Criminal Law’ New Criminal Law Review, 11: 529

Downes, D. and Van Swaaningen, R. (2007) 'The road to dystopia? Changes in the penal climate of the Netherlands" in M. Tonry and E Bijleveld (eds.) Crime and Justice in the Netherlands. Chicago: University of Chicago Press

Dubber, M. D. (2001) 'Policing Possession: The War on Crime and the End of Criminal Law' Journal of Criminal Law and Criminology, 91: 829

Duff, R. A. (2001) Punishment, Communication and Community. New York: Oxford University Press (2007) Answering for Crime. Oxford: Hart , Farmer, L., Marshall, S. E. and Tadros, V (2007) The Trial on Trial (3): Towards a Normative Theory of the Criminal Trial. Oxford: Hart

Floud, J. and Young, W. (1981) Dangerousness and Criminal Justice. London: Heinemann Goldman, A. I. (1979) 'The Paradox of Punishment' Philosophy and Public Affairs, 9: 42 Harcourt, B. E. (1999) 'The Collapse of the Harm Principle' Journal of Criminal Law and Criminology, 90: 109

Hart, H. L. A. (1968) 'Prolegomenon to the Principles of Punishment', in Hart, Punishment and Responsibility. Oxford: Oxford University Press (1994) The Concept of Law ( $2^{\text {nd }}$ ed). Oxford, Oxford University Press

Husak, D. N. (2002) Legalize This! The Case for Decriminalizing Drugs. London: Verso (2004) 'The Criminal Law as a Last Resort' Oxford Journal of Legal Studies, 24: 207 (2007) Overcriminalization. Oxford: Oxford University Press

Jareborg, N. (2005) 'Criminalization as Last Resort (Ultima Ratio)' Ohio State Journal of Criminal Law, 2: 521

Kelsen, H. (1945) General Theory of Law and State (trans A Wedberg). Cambridge, Mass: Harvard University Press

Lacey, N. (1988) State Punishment. London: Routledge

Loader, I. (2010) 'For Penal Moderation', in this issue 
Marshall, S. E. and Duff, R. A. (1998) 'Criminalization and Sharing Wrongs' Canadian Journal of Law \& Jurisprudence, 11: 7

Moore, M. S. (1997) Placing Blame: A General Theory of the Criminal Law. Oxford: Oxford University Press (2009) 'A Tale of Two Theories' Criminal Justice Ethics, 28: 27

Nagel, T. (1978) Mortal Questions. Cambridge: Cambridge University Press

Pettit, P. (1999) Republicanism: A Theory of Freedom and Government. Oxford: Oxford University Press

Playfair, G. (1971) The Punitive Obsession. London: Gollancz

Raz, J. (1986) The Morality of Freedom. Oxford: Oxford University Press

Stewart, H. (2010) 'The Limits of the Harm Principle' Criminal Law and Philosophy, 4:

Tadros, V. (2007) 'Justice and Terrorism' New Criminal Law Review, 10: 658

von Hirsch, A. (1993) Censure and Sanctions. Oxford: Oxford University Press (1996) 'Extending the Harm Principle: "Remote" Harms and Fair Imputation', in A. P. Simester and A. T. H. Smith (eds), Harm and Culpability (Oxford: Oxford University Press), 259 and Simester, A. P. (eds.) (2006) Incivilities: Regulating Offensive Behaviour. Oxford: Hart

Weigend, T. (1988) 'The Legal and Practical Problems Posed by the Difference between Criminal Law and Administrative Penal Law' Revue Internationale de Droit Pénal, 59: 67

Zedner, L. (2007) 'Preventive Justice or Pre-punishment? The Case of Control Orders' Current Legal Problems, 60: 174 (2009) Security. London: Routledge 